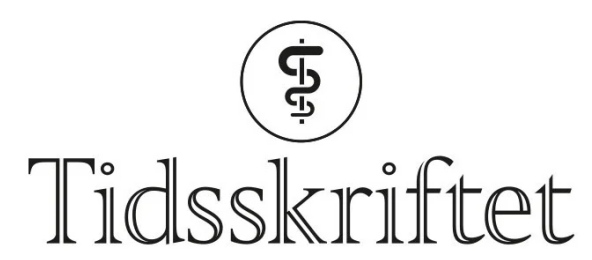

DEN NORSKE LEGEFORENING

\title{
Oddmund Johannes Johansen
}

\author{
MINNEORD
}

GUNNAR KNUTSEN

BJARNE A. OLSEN

JAN ELVENES

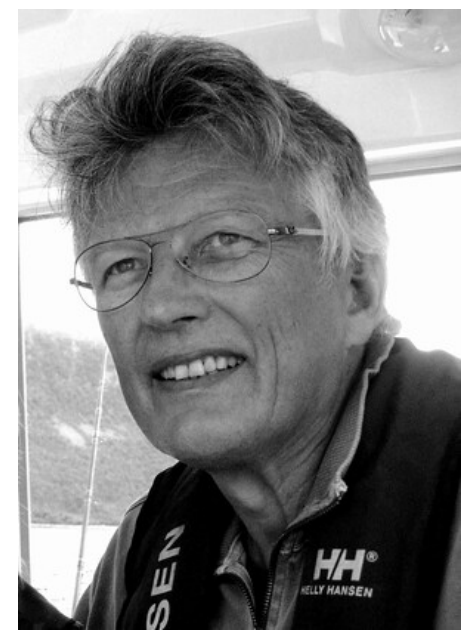

Det var med stor sorg vi mottok budskapet om at professor emeritus Oddmund Johannes Johansen (f. 1948) døde 1. juli 2021 på en av sine mange fiske- og fjellturer.

Han var svært glad i den nordnorske naturen. Som guttunge og ungdom ble han tatt med både ut på havet og opp i fjellene på fiske- og jaktturer, blant annet av mange av sine slektninger.

Han vokste opp i Nord-Troms, mest i Lyngen, men også i Kåfjord. Han studerte medisin ved Universitetet i Troms $\emptyset$ og ble uteksaminert med det første kullet med medisinstudenter i Tromsø. Etter fullført turnustid begynte han å jobbe på kirurgisk avdeling ved sykehuset i Troms $\emptyset$ og ble etter hvert spesialist i ortopedisk kirurgi. Han tok medisinsk doktorgrad, og avhandlingen hans dreide seg om brudd, endorfiner og metabolisme. Opp gjennom årene veiledet han flere doktorgradskandidater. Han ble så etter hvert den tredje i Troms $\emptyset$ til å få tittelen professor 1 i ortopedisk kirurgi. 
Hele sin aktive karriere hadde han interesse for forskning på brusk. Han var med som gründer i flere bedrifter på feltet. Som pensjonist brukte han mye av sin tid på denne forskningen.

Noen av forskningsresultatene ledet til at det i juni 1996 for første gang i Norge ble gjort transplantasjon av levende bruskceller til en pasient. Forskningen førte videre til at sykehuset i Troms $\emptyset$ allerede på nittitallet fikk etablert et eget laboratorium for dyrkning av bruskceller til klinisk bruk. I samarbeid med professor Lars Peterson i Gøteborg ble verdens første transplantasjon av bruskceller til hofteledd utført i Tromsø i 1999. Helt til det siste var Oddmund entusiastisk og aktiv i forskning innenfor dette feltet.

Oddmund var en positiv person, alltid omgjengelig og hjelpsom, både i smått og stort.

Våre tanker går til hans nærmeste familie. Vi lyser fred over Oddmund Johannes Johansens minne.

På vegne av kollegaer og venner.

Publisert: 13. desember 2021. Tidsskr Nor Legeforen. DOI: 10.4045/tidsskr.21.0820

(C) Tidsskrift for Den norske legeforening 2023. Lastet ned fra tidsskriftet.no 26. april 2023. 